Diabetologia 9, 243--250(1973)

(C) by Springer-Ver]ag 1973

\title{
ORIGINALS
}

\section{Effects of Feeding and Fasting on the Insulin Secretory Response to Glucose and Sulfonylureas in Intact Rats and Isolated Perfused Rat Pancreas*}

\author{
R.S. Bosboom, J. Zweens and P. R. Bouman** \\ Endocrine Research Unit, Department of Pharmacology, University of Groningen, The Netherlands
}

Received: August 12, 1972, accepted: March 3, 1973

\begin{abstract}
Summary. In intact rats $16 \mathrm{~h}$ of fasting reduced the plasma insulin response to i.v. stimulation with either glucose, tolbutamide or glibenclamide by $50-80 \%$, without affecting the extractable insulin content of the pan. creas. In subsequent studies with the isolated perfused rat pancreas two distinet patterns of insulin release could be discerned during the secondary phase. In the fed state, glucose $1.5 \mathrm{mg} / \mathrm{ml}$ induced a more or less constant elevation of the insulin secretion rate over 30 min. (type I). At glucose concentrations of 2 and $3 \mathrm{mg} / \mathrm{ml}$ the release pattern was characterized by progressively increasing secretion rates (type II pattern). Infusion of tolbutamide $(0.2 \mathrm{mg} / \mathrm{ml})$ lowered the threshold for glucose stimulation and induced both patterns of secretion at lower glucose concentrations. Fasting for $24 \mathrm{~h}$ caused a $70-80 \%$ in-
\end{abstract}

hibition of insulin secretion per $30 \mathrm{~min}$ at glucose levels of 1.5 and $2 \mathrm{mg} / \mathrm{ml}$. Decreased glucose sensitivity was indicated by a shift to the right of the entire dose-response curve for glucose and by reduced inhibition $(30 \%)$ at a glucose level of $3 \mathrm{mg} / \mathrm{ml}$. The effect of tolbutamide was also strongly diminished. The percent inhibition of the response to tolbutamide at different levels of glucose showed a pattern of inhibition similar to that observed with glucose alone. These findings suggest that the glucose-dependent release mechanism is highly sensitive to relatively short periods of fasting.

Key-words: Fasting, plasma insulin, pancreatic insulin content, pancreas perfusion, glucose, tolbutamide, glibenclamide, insulin secretion patterns.

\section{Introduction}

Since 1960 the direct stimulatory effect of glucose on pancreatic insulin release has been confirmed by a variety of new techniques such as in vitro incubation of pieces of pancreatic tissue $[2,8,29]$, perfusion of isolated rat pancreas $[13,32]$, in vitro incubation of isolated islets of Langerhans $[19,27]$ and more recently perifusion of pancreatic tissue in vitro $[7,17]$. Many of these studies were conducted with pancreas from fasted animals in order to establish basal conditions and to reduce scatter of experimental data. Likewise, fasted animals were often used in numerous studies on the insulinogenic action of hypoglycaemic sulfonylureas with incubated pancreas $[3,8]$ or with isolated perfused rat pancreas $[1,9,11,15,21]$. Notable exceptions are the recent studies by Loubatières el al. [23, 24, 25] and by Malaisse et al. [4, 26, 28]. Thus, much of our current knowledge on insulin secretion and its regulation pertains specifically to islet function in the fasting state.

The effect of fasting as such on direct parameters of islet function has received relatively little attention so far. In intact mice fasting over $24 \mathrm{~h}$ was reported to enhance the plasma insulin response to tolbutamide

* Presented in part at the Sixth Annual Meeting of the European Association for the Study of Diabetes, Warsaw, September 1970.

** Supported by a grant from the Netherlands Organization for the Advancement of Pure Research (Z.W.O.).
[10]. In the intact rat, on the other hand, fasting and starvation were shown to reduce the insulin secretory response to the combined administration of anti-insulin serum with either glucose or tolbutamide $[28,30]$ or to glucose alone [12]. These in vivo studies are difficult to interpret in view of differences between fasted and fed animals with respect to the initial plasma glucose level and its consecutive changes. However, in vitro studies with pieces of pancreas [30] and with isolated islets [5] have supplied strong evidence that fasting and starvation for 1 to 4 days severely impairs the secretory response to glucose stimulation.

The present perfusion experiments allow a more detailed analysis of this phenomenon, since this procedure permits continuous monitoring of secretion rates, characterization of patterns of secretion and determination of total insulin secretion during application of experimental stimuli through the vascular system under highly standardized conditions.

\section{Materials and Methods}

\section{Animals and Diets}

Male albino rats of an inbred Wistar strain were used throughout this study. In vivo experiments and pancreas extractions were performed on animals of $160-180 \mathrm{~g}$ body weight. For perfusion experiments the pancreas was taken from animals in the weight range of $240-290 \mathrm{~g}$.

The experiments were performed either on ad libitum fed rats (deprived of food for $2 \mathrm{~h}$ preceding each experi- 
ment) or on animals which had been fasted for $16 \mathrm{~h}$ (in vivo studies) or for $24 \mathrm{~h}$ (perfusion experiments). All rats were allowed free access to water.

For perfusion experiments with pancreas of fed rats it was inconvenient to use animals fed with regular pellet diet (Muracon 1, Trouw Ltd., Amsterdam). Bulk and food remnants often caused obstruction of the gastric cannula for drainage of gastric secretions, which resulted in a diminished flow rate during perfusion. This could be avoided by the use of rats which had been kept for 2 days on a bulk-less powder diet of baby food (Farilacid B, kindly supplied by Nutricia Ltd., Zoetermeer, Holland). The effect of this diet was also investigated in vivo. The composition of both diets as supplied by the manufacturers is given in Table 1 . The rats did not change their caloric intake when the diet was changed from pellets to powder.

Table 1. Composition of the diets

\begin{tabular}{lrc}
\hline & pellets & powder \\
\hline carbohydrate & $\mathbf{5 3 . 5} \%$ & $61.0 \%$ \\
digestable protein & $\mathbf{1 8 . 0} \%$ & $\mathbf{1 9 . 9} \%$ \\
remaining protein & $\mathbf{3 . 4} \%$ & - \\
fat & $\mathbf{4 . 6 \%}$ & $\mathbf{9 . 1} \%$ \\
lactic acid & $-5.3 \%$ & $3.1 \%$ \\
minerals & $11.5 \%$ & $4.4 \%$ \\
liquid & $\mathbf{3 . 7} \%$ & $2.5 \%$ \\
cellulose & $399 / 100 \mathrm{~g}$ & $\mathbf{4 1 7} / 100 \mathrm{~g}$ \\
calories & \\
\hline
\end{tabular}

\section{In Vivo Experiments}

Anaesthosia was induced by an intraperitoneal injection of pentobarbital (Nembutal ${ }^{\otimes}, 4.5 \mathrm{mg} / 100 \mathrm{~g}$ body weight). After $15 \mathrm{~min}$ the rats were given an intravenous load of either glucose $(100 \mathrm{mg} / 100 \mathrm{~g})$, tolbutamide $15 \mathrm{mg}$ ) $100 \mathrm{~g})$, or glibenclamide ${ }^{1}(10 \mu \mathrm{g} / 100 \mathrm{~g})$. Immediately before and at 10 and $30 \mathrm{~min}$ after administration of the test substance, blood from the orbital plexus was collected. in heparinized test tubes to be analysed for plasma insulin and glucose concentrations. Each of the three mentioned insulinogenic substances was tested at different occasions. Ad libitum fed and fasted rats were examined on the same day.

\section{Perfusion Experiments}

The pancreas with the stomach, the spleen and part of the duodenum, was prepared and perfused according to the method of Grodsky and collaborators $[13,14]$, with slight modifications. The perfusion medium was KrebsRinger bicarbonate solution [33] with $40 \mathrm{mg} / \mathrm{ml}$ of demineralized bovine albumin (Poviet Producten Ltd., Amsterdam). Ampicillin (Penbritin ${ }^{\circledR}$, Beecham Research Laboratories, Brentford, England) in a concentration of $10 \mu \mathrm{g} / \mathrm{ml}$ was added. Flow rates were established at $4 \mathrm{ml} / \mathrm{min}$ by adjusting the pressure between 30 and $60 \mathrm{~mm} \mathrm{Hg}$. This flow rate was chosen since flow rates of 10-12 $\mathrm{ml} / \mathrm{min}$, as indicated by Grodsky et al. $[9,14]$, often caused leakage of perfusion fluid from the preparation. The perfusion medium was equilibrated with $95 \%$ oxygen and $5 \%$ carbon dioxide resulting in a $\mathrm{pH}$ (meas. ured with a continuous flow electrode) of 7.35 . The arterial oxygen tension (measured with an oxygen electrode) was $400-500 \mathrm{~mm} \mathrm{Hg}$, whereas the venous oxygen tension. was $185-215 \mathrm{~mm} \mathrm{Hg}$. The high oxygen reserve in the venous effuent indicates sufficient oxygenation of the perfused tissue at the flow rate of $4 \mathrm{ml} / \mathrm{min}$.

1 Tolbutamide (Reinsubstanz) and glibenclamide (HB 419) were generously given by Farbwerke Hoechst, A.G., Frankfurt (M.).
During an initial equilibration period of $30 \mathrm{~min}$ the preparation was perfused while recirculating the medium. The glucose concentration over this period was $1 \mathrm{mg} / \mathrm{ml}$. In experiments without glucose or with glucose concentrations of 0.6 and $1 \mathrm{mg} / \mathrm{ml}$ these concentrations were maintained throughout the whole experiment. After equilibration, the recirculation was discontinued and the effluent was quantitatively collected over $5 \mathrm{~min}$ intervals. The first two of these fractions were used to measure the secretion of insulin during a control period of $10 \mathrm{~min}$. The subsequent test period of $30 \mathrm{~min}$ (six fractions) was begun by adding variable amounts of glucose and/or tolbutamide to a concentration of $0.2 \mathrm{mg} / \mathrm{ml}$. The substances were added into the reservoir during the control period in order to reach the preparation in the first minute of the test period. The desired glucose concentration at the arterial inflow was reached after the initial $4-5 \mathrm{~min}$ of the test period. Samples of the collected fractions were analysed for glueose and insulin concentrations.

\section{Extraction and Assay Procedures}

For determination of the pancreatic insulin content, the pancreas was removed after decapitation of the animal, weighed and quickly frozen in liquid nitrogen. The frozen tissue was stored at $-40^{\circ} \mathrm{C}$ until extraction. The tissue was homogenized in acid-aleohol (conc. HCl $1.5 \%$ $v / v$, ethanol $76 \% v / v$ ) and the supernatant was diluted with veronal buffer containing $2.5 \mathrm{mg} / \mathrm{ml}$ of bovine albumin.

Plasma samples and samples of the extracts and perfusates (if necessary diluted with veronal buffer) were stored at $-20^{\circ} \mathrm{C}$ until assay.

Crystalline rat insulin was prepared from about $1 \mathrm{~kg}$ of rat pancreas collected in our laboratory ${ }^{2}$. This material (Lot nr. R. 564; biological potency $21 \mathrm{U} / \mathrm{mg}$ ) was used as the standard for insulin determinations by radioimmunoassay and also served for the preparation of specific antirat insulin sera.

Immunoreactive insulin (IRI) in the samples mentioned before was determined with a slight modification of the method of Yalow and Berson [34], as previously described [18]. Antisera were obtained by immunization of guinea pigs with crystalline rat insulin. They were carefully selected for immunoassay purposes. The antiserum for the present study was used at a concentration of 1 : 40000 , which binds $50-60 \%$ of added insulin ${ }^{131}$ I (final concentration $1.5-2 \mathrm{ng} / \mathrm{ml}$ ). Beef insulin-131 I was used as a radioactive tracer since this preparation appeared to be more stable than rat insulin $131 \mathrm{~T}$.

Glucose coneentrations were measured with a Technicon Autoanalyzer ${ }^{\circ}$, adapted for the ferricyanide method.

The results were tested for statistical significance by means of Wilcoxon's two sample test or Student's t-test. The level of significance was chosen at $p<0.05$.

\section{Results}

\section{In Vivo Experiments}

The effect of intravenous administration of glucose, tolbutamide, and glibenclamide on plasma glucose and insulin levels in fed and 16 -h-fasted rats is shown in Table 2. Peak values of plasma insulin were observed 10 min after the administration of these substances. Fasting reduced the initial plasma insulin content to very low levels and caused a consistent decrease in the

2 Extraction and purification of this material were kindly executed by the NOVO Research Institute, Copenhagen, through the courtesy of Dr. J. Schlichtlzrull. 
peak values observed after injection of the various insulinogenic substances.

Plasma glucose in fed rats appeared to have already decreased 10 min after the administration of tolbutamide and glibenclamide. At $30 \mathrm{~min}$ the fall in plasma glucose in these animals was even more prominent. Fasted rats, on the other hand, failed to exhibit a hypoglycaemic response at $10 \mathrm{~min}$, and the decrease observed at 30 min was only small and insignificant when compared with fed rats.

The difference in the insulin secretory response between fed and fasted rats was quantified by calculat-
The results of additional experiments indicate that neither fasting for $24 \mathrm{~h}$ nor feeding of the powder diet significantly affected the total extractable insulin content. The mean values of 10 extractions were (U/ pancreas \pm s.e.m.) $1.54 \pm 0.11$ (fasted), $1.75 \pm 0.11$ (fed with powder) and $1.59 \pm 0.14$ (fed with pellets).

\section{Perfusion of Fed Rat Pancreas}

The response of perfused pancreas of fed rats to continuous stimulation with glucose is depicted by the upper row of diagrams in Fig.1. In each experiment the

Table 2. Plasma glucose and insulin levels in fed and 16-h-fasted rats after intravenous administration of glucose and sulfonylureas

\begin{tabular}{|c|c|c|c|c|c|c|c|}
\hline \multirow[t]{2}{*}{ Test substance } & \multirow[t]{2}{*}{$\begin{array}{l}\text { Nutritional } \\
\text { status }\end{array}$} & \multicolumn{3}{|c|}{$\begin{array}{l}\text { Plasma glucose } \\
\mathrm{mg} / 100 \mathrm{ml} \pm \text { s.e.m. }(\mathrm{n}=4)\end{array}$} & \multicolumn{3}{|c|}{$\begin{array}{l}\text { Plasma insulin } \\
\mu \mathrm{U} / \mathrm{ml} \pm \text { s.e.m. }(\mathrm{n}=4)\end{array}$} \\
\hline & & $0^{\prime}$ & $10^{\prime}$ & $30^{\prime}$ & $0^{\prime}$ & $10^{\prime}$ & $30^{\prime}$ \\
\hline $\begin{array}{l}\text { Glucose } \\
100 \mathrm{mg} / 100 \mathrm{~g}\end{array}$ & $\begin{array}{l}\text { fed } \\
\text { fasted }\end{array}$ & $\begin{array}{r}147 \pm 7 \\
98 \pm 5\end{array}$ & $\begin{array}{l}366 \pm 9 \\
411 \pm 15\end{array}$ & $\begin{array}{l}187 \pm 16 \\
260 \pm 3\end{array}$ & $\begin{array}{r}15 \pm 6 \\
0 \pm 0\end{array}$ & $\begin{array}{l}79 \pm 7 \\
34 \pm 12\end{array}$ & $\begin{array}{l}30 \pm 6 \\
33 \pm 8\end{array}$ \\
\hline $\begin{array}{l}\text { Tolbutamide } \\
5 \mathrm{mg} / 100 \mathrm{~g}\end{array}$ & $\begin{array}{l}\text { feda } \\
\text { fasted }\end{array}$ & $\begin{array}{r}143 \pm 2 \\
89 \pm 4\end{array}$ & $\begin{array}{r}113 \pm 1 \\
91 \pm 3\end{array}$ & $\begin{array}{l}63 \pm 1 \\
67 \pm 7\end{array}$ & $\begin{array}{r}27+4 \\
9 \pm 1\end{array}$ & $\begin{array}{l}89 \pm 5 \\
30 \pm 9\end{array}$ & $\begin{array}{l}59 \pm 9 \\
29 \pm 3\end{array}$ \\
\hline $\begin{array}{l}\text { Glibenclamide } \\
10 \mu \mathrm{g} / 100 \mathrm{~g}\end{array}$ & $\begin{array}{l}\text { fed } \\
\text { fasted }\end{array}$ & $\begin{array}{r}152 \pm 4 \\
92 \pm 5 \\
\end{array}$ & $\begin{array}{l}119 ! 2 \\
109 \pm 8\end{array}$ & $\begin{array}{l}66 \pm 4 \\
85 \pm 2 \\
\end{array}$ & $\begin{array}{r}28 \pm 5 \\
4 \pm 2 \\
\end{array}$ & $\begin{array}{r}108 \pm 15 \\
19 \pm 3\end{array}$ & $\begin{array}{l}50 \pm 3 \\
16 \pm 2 \\
\end{array}$ \\
\hline $\begin{array}{l}\text { Glibenclamide } \\
10 \mu \mathrm{g} / 100 \mathrm{~g}\end{array}$ & $\begin{array}{l}\text { fed (powder) } \\
\text { (pellets) } \\
\text { fasted }\end{array}$ & $\begin{array}{r}142 \pm 3 \\
144 \pm 4 \\
92 \pm 5\end{array}$ & $\begin{array}{r}98 \pm 3 \\
112 \pm 5 \\
106 \pm 6\end{array}$ & & $\begin{array}{r}30 \pm 2 \\
38 \pm 4 \\
3 \pm 2\end{array}$ & $\begin{array}{r}114 \pm 23 \\
108 \pm 14 \\
20 \pm 4\end{array}$ & \\
\hline
\end{tabular}

a Fed with pellets unless otherwise indicated.

Table 3. Effect of fasting for 16 h on the insulin secretory response ( $\triangle$ plasma IRI at $\left.10^{\prime}\right)$ to glucose and sulfonylureas in vivo

\begin{tabular}{llll}
\hline Test substance & $\begin{array}{l}\text { Fed rats } \\
\text { (pellets) }\end{array}$ & Fasted rats & $\begin{array}{l}\% \\
\text { of response in fed } \\
\text { rats } \\
\text { (pellets) }\end{array}$ \\
\hline Glueose & $+64 \mu \mathrm{U} / \mathrm{ml}$ & $+34 \mu \mathrm{U} / \mathrm{ml}$ & $53 \%$ \\
Tolbutamide & $+62 \mu \mathrm{U} / \mathrm{ml}$ & $+21 \mu \mathrm{U} / \mathrm{ml}$ & $34 \%$ \\
Glibenclamide & $+80 \mu \mathrm{U} / \mathrm{ml}$ & $+15 \mu \mathrm{U} / \mathrm{ml}$ & $19 \%$ \\
Glibenclamide & $+70 \mu \mathrm{U} / \mathrm{mI}$ & $+17 \mu \mathrm{U} / \mathrm{ml}$ & $24 \%$ \\
\hline
\end{tabular}

a Calculated from data in Table 2.

ing the net increase in plasma insulin at $10 \mathrm{~min}$. The results are shown in Table 3 . Overnight fasting appeared to reduce the secretory response to glucose stimulation by some $50 \%$ and by approximately $70-$ $80 \%$ in the case of stimulation with tolbutamide or glibenclamide.

\section{Total Pancreatic Insulin Content}

Overnight fasting (16 h) failed to affect extractable pancreatic insulin in rats previously fed with the pellet diet. Parallel extractions yielded a pancreatic insulin content of $1.17 \pm 0.05 \mathrm{U} /$ pancreas in fasted rats versus $1.15 \pm 0.05 \mathrm{U} /$ pancreas in fed animals. Both values represent the mean of 16 extractions \pm s.e.m. control secretion rate was established by perfusion with glucose $1 \mathrm{mg} / \mathrm{ml}$ over a control period of $10 \mathrm{~min}$. At this concentration of glucose insulin secretion proceeded at a low and constant level amounting to 0.2 $\mathrm{mU} / 5 \mathrm{~min}$ or to $1.4 \pm 0.2 \mathrm{mU}$ when converted to total secretion over $30 \mathrm{~min}$ (mean of 32 perfusions).

Elevation of the glucose concentration to either $1.5,2$ or $3 \mathrm{mg} / \mathrm{ml}$ caused an immediate rise in insulin secretion over the initial $5 \mathrm{~min}$. Insulin secretion over this brief initial period appeared not to be related to the degree of glucose stimulation. Dose-dependent effects of continuous glucose stimulation only became apparent during the subsequent phases of the test period, which allowed the distinction of two different patterns of enhanced secretion. 
At a glucose concentration of $1.5 \mathrm{mg} / \mathrm{ml}$ the insulin secretion rate remained elevated at a more or less constant level, which did not differ much from the level observed during the initial 5 min. This pattern was designated as a type I pattern. A second pattern, designated as type II, was observed with glucose concentrations of 2 and $3 \mathrm{mg} / \mathrm{ml}$. This pattern is characterized by progressively increasing secretion rates over the entire test period. The occurrence of the type II pattern contributes substantially to the total output of insulin at high glucose concentrations.

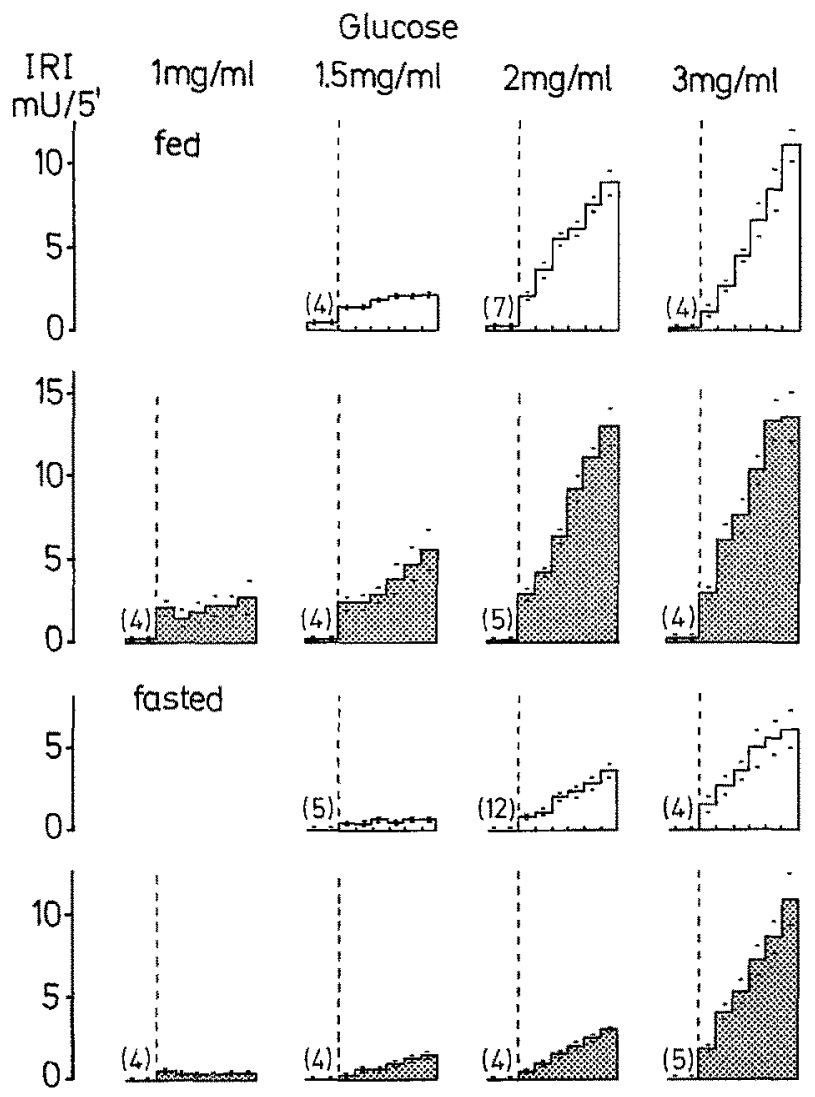

Fig. 1. Insulin secretion patterns obtained with perfused pancreas from fed and 24 -h-fasted rats during continuous stimulation with glucose (plain) or glucose and tolbutamide $(0.2 \mathrm{mg} / \mathrm{ml})$ (shaded) over test periods of $30 \mathrm{~min}$.

Mean \pm s.e.m., number of experiments in brackets

The overall dose-response relation between glucose concentration and total insulin output from the pancreas of fed control rats is shown in Fig. 2. This relation is characterized by a sigmoid curve (semi-logarithmic plot) showing its steepest slope between glucose concentrations of 1 and $2 \mathrm{mg} / \mathrm{ml}$. The curve also includes data from perfusion experiments with glucose $0.6 \mathrm{mg} / \mathrm{ml}$ (not shown in Fig. 1), which indicate that in the fed state a glucose concentration of $1 \mathrm{mg} / \mathrm{ml}$ is the minimal effective in stimulating insulin release.

Addition of tolbutamide $(0.2 \mathrm{mg} / \mathrm{ml})$ to the perfusion medium appeared to modify the secretory re- sponse to glucose stimulation both quantitatively and qualitatively (Fig. 1, second row of diagrams). At glucose concentrations of $1.5,2$ and $3 \mathrm{mg} / \mathrm{ml}$ the stimulation of insulin secretion over the initial 5 min was enhanced by the presence of tolbutamide. In addition, previously ineffective glucose concentrations of 0.6 and $1 \mathrm{mg} / \mathrm{ml}$ became stimulatory in the presence of tolbutamide, the initial increase in secretion rate being followed by a continuous and similar elevation of in. sulin secretion over the further test period. Thus, tolbutamide induced a type I pattern of secretion at glucose concentrations which were not stimulatory as such. With glucose $1.5 \mathrm{mg} / \mathrm{ml}$, the presence of tolbut-

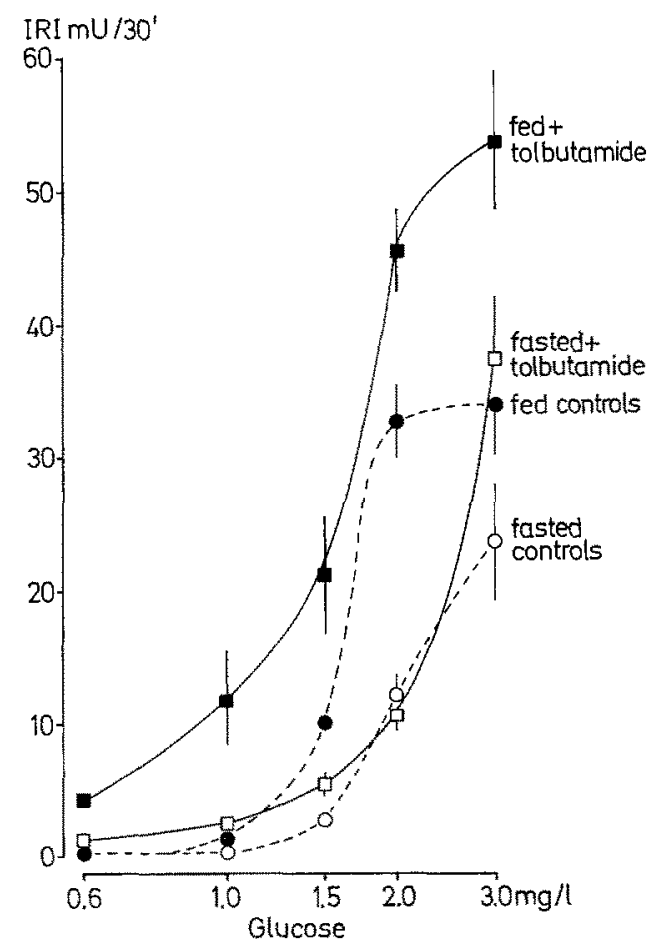

Fig. 2. Dose-response relation for continuous glucose stimulation of insulin secretion by perfused pancreas of fed and 24-h-fasted rats in the presence and absence of tolbutamide $(0.2 \mathrm{mg} / \mathrm{ml})$. Mean total insulin output over $30 \mathrm{~min}+$ s.e.m., number of experiments as in Fig. 1, or, if not given there, $n=4$. When the s.e.m. is not shown it is to small to be depicted.

amide appeared to change the original type I pattern of secretion into a type II pattern, which in the absence of tolbutamide only occurred at glucose concentrations of 2 and $3 \mathrm{mg} / \mathrm{ml}$. At the latter glucose concentrations tolbutamide also caused a marked increase in the overall magnitude of the type II pattern of response to glucose.

The effect of tolbutamide on the total secretory response of fed rat pancreas to glucose stimulation is depicted in Fig. 2. By the presence of tolbutamide the dose-response curve for glucose was shifted upward and to the left due to a marked increase in the total 
response with glucose $3 \mathrm{mg} / \mathrm{ml}$ and the appearance of glucose sensitivity at concentrations of 0.6 and $1 \mathrm{mg} /$ $\mathrm{ml}$.

Additional experiments were performed to investigate the effects of tolbutamide in the absence of glucose. When glucose was omitted from the perfusion medium during the routine $30 \mathrm{~min}$ of equilibration (see Materials and Methods), subsequent perfusion with tolbutamide alone failed to affect insulin secretion in 3 out of 5 experiments. In the remaining 2 experiments, insulin secretion in the presence of tolbutamide the lower two series of diagrams in Fig. 1. Fasting did not affect the general qualitative patterns of response to these stimuli, in the sense that type I and type II patterns of secretion did occur at the same concentrations of glucose as previously observed in fed rat pancreas. However, at glucose concentrations of 1.5 and $2 \mathrm{mg} / \mathrm{ml}$ the overall magnitude of the response was considerably reduced both in the absence and presence of tolbutamide. This appeared to be due to a significant quantitative decrease in the type I secretion pattern and a sluggish development of type II patterns of re-

Table 4. Effect of fasting on total insulin secretion from perfused rat pancreas at different levels of glucose in the absence and presence of tolbutamide $(0.2 \mathrm{mg} / \mathrm{ml})$

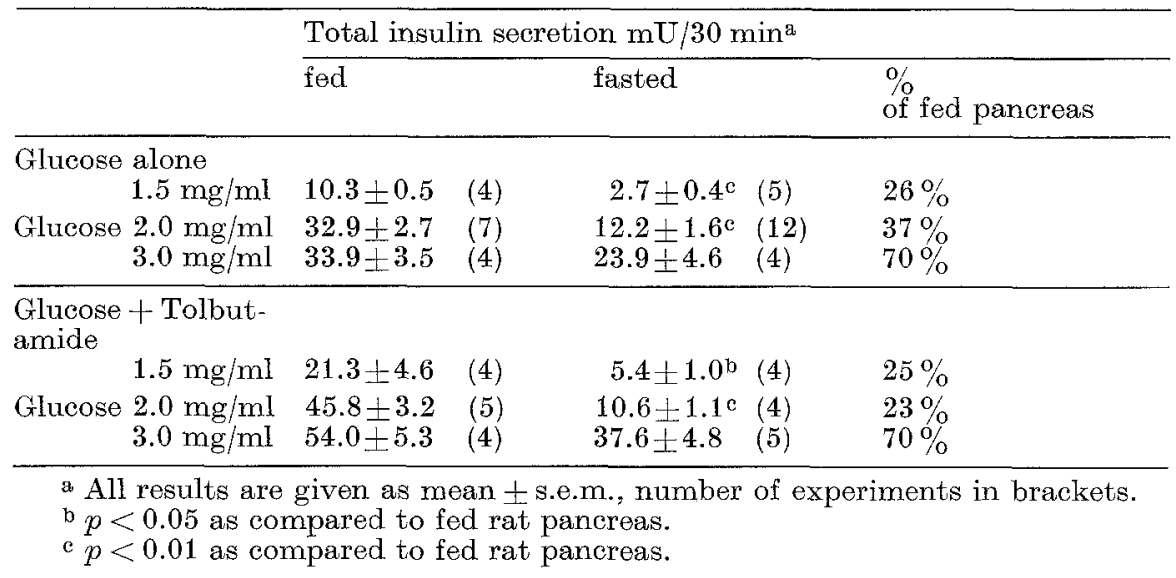

Table 5. Effect of fasting on the supplementary output of insulin from perfused pancreas as induced by tolbutamide $(0.2 \mathrm{mg} / \mathrm{ml})$ at different glucose concentrations

\begin{tabular}{llcc}
\hline $\begin{array}{l}\text { Glucose concentra- } \\
\text { tion }\end{array}$ & \multicolumn{4}{l}{$\Delta$ insulin secretion $\mathrm{mU} / 30 \mathrm{~min}^{\mathrm{a}}$} & \\
\cline { 2 - 4 } & fed & fasted & $\begin{array}{c}\% \\
\text { of fed pancreas }\end{array}$ \\
\hline $1.0 \mathrm{mg} / \mathrm{ml}$ & $+11.2 \pm 3.3$ & $+2.1 \pm 0.2^{\mathrm{b}}$ & $19 \%$ \\
$1.5 \mathrm{mg} / \mathrm{ml}$ & $+11.0 \pm 4.6$ & $+2.7 \pm 1.0^{\mathrm{c}}$ & $25 \%$ \\
$2.0 \mathrm{mg} / \mathrm{ml}$ & $+12.9 \pm 4.2$ & $-1.6 \pm 2.0^{\mathrm{c}}$ & $-13 \%$ \\
$3.0 \mathrm{mg} / \mathrm{ml}$ & $+20.1 \pm 6.4$ & $+13.7 \pm 6.7$ & $68 \%$ \\
\hline
\end{tabular}

a Calculated by subtraction of secretion values observed at the specified glucose concentrations in the absence of tolbutamide ( $土$ s.e.m.).

$\mathrm{b} p<0.05$ as compared to fed rat pancreas.

c $p<0.01$ as compared to fed rat pancreas.

varied between 0.06 and $0.4 \mathrm{mU} / 5 \mathrm{~min}$. The secretory response to glucose stimulation was not impaired under these conditions. Further experiments showed that the effectiveness of tolbutamide alone is strongly dependent on the experimental conditions. When tolbut amide was added immediately at the start of the perfusion (i.e. at the beginning of the equilibration period), a small but consistent increase in insulin release was observed in the absence of glucose.

\section{Perfusion of Fasted Rat Pancreas}

The effect of $24 \mathrm{~h}$ fasting on the response of perfused pancreas to glucose and tolbutamide is shown in sponse. The latter phenomenon is particularly evident at a glucose concentration of $2 \mathrm{mg} / \mathrm{ml}$.

As shown in Table 4, fasting reduced the total insulin secretory response to glucose stimulation (1.5 and $2 \mathrm{mg} / \mathrm{ml}$ ) by some $70-80 \%$ both in the absence and presence of tolbutamide. In contrast, the inhibitory effect of fasting was considerably less at a glucose concentration of $3 \mathrm{mg} / \mathrm{ml}$. These phenomena appear not to be related to the presence or absence of tolbutamide. The inhibitory effect of fasting on the response to tolbutamide likewise appeared to depend on the glucose concentration employed (Table 5). At the highest glucose concentration $(3 \mathrm{mg} / \mathrm{ml})$ inhibition of the 
effect of tolbutamide was small in comparison to the inhibition observed at lower concentrations of glucose.

The effect of fasting is further illustrated by the dose-response curves for glucose stimulation as shown in Fig. 2. Both in the absence and presence of tolbutamide, fasting induced a marked shift to the right, indicating reduced sensitivity to glucose stimulation, which is particularly evident at glucose concentrations of 1.5 and $2 \mathrm{mg} / \mathrm{ml}$. The curves suggest that maximal stimulation of fasted rat pancreas can only be attained at glucose concentrations in excess of $3 \mathrm{mg} / \mathrm{ml}$. The two curves for fasted rat pancreas (with and without tolbutamide) furthermore demonstrate a modest increase in responsiveness to glucose by additional stimulation with tolbutamide, which contrasts with the high sensitivity of fed rat pancreas in this respect.

\section{Discussion}

The effect of fasting on the insulin secretory response to glucose or sulfonylureas in vivo as presently observed are in agreement with the results of earlier studies in intact rats $[12,28,30]$. A $16 \mathrm{~h}$ period of fasting appeared to reduce the secretory response to glucose, tolbutamide or glibenelamide by some $50-$ $80 \%$, depending on the type of stimulus used. Similar findings were made on further analysis of this phenomenon with isolated perfused rat pancreas.

The effects of continuous perfusion with stimulating concentrations of glucose are essentially similar to those observed by Grodsky et al. in fasted rat pancreas $[9,16]$ and to the results of Loubatières et al. obtained with perfused pancreas from fed animals $[23$, $24,25]$. However, some aspects of the present secretion profiles should be emphasized.

The total output of insulin over $30 \mathrm{~min}$ of continuous stimulation with glucose is mainly caused by enhanced secretion rates during the secondary phase, which follows a brief initial peak response. In the present study the initial peak response was obliterated by the collection of the effluent over 5 min intervals. However, its occurrence was established when 1 min collections were made over the initial $5 \mathrm{~min}$ of stimulation.

Analysis of the secretion profiles revealed that glucose may trigger two, hitherto unrecognized, basically different patterns of secondary phase secretion. The type I pattern is characterized by a relatively constant level of enhanced secretion, which contrasts with the progressive increase in secretion rates of the type II pattern. The latter pattern is triggered by glucose concentrations in excess of $1.5 \mathrm{mg} / \mathrm{ml}$. From studies by Curry et al. [9] it would appear that the development of the type II pattern may be selectively inhibited by puromycin. Likewise, low calcium levels seem to be inbibitory in this respect. Presumably, the latter effect is less specific since low calcium, in contrast to puromyoin, also inhibits the initial peak response to glucose stimulation. Further work will be needed to elucidate the mechanism behind these two distinct patterns of secretion.

The observed threshold values for glucose stimulation in fed and fasted pancreas ( 1 and $1.5 \mathrm{mg} / \mathrm{ml}$ respectively) are in accordance with results of previous incubation and perfusion studies by various authors $[16,23,25,29]$. Fed pancreas not only responds at lower concentrations of glueose, but also secretes more insulin at a given increase in glucose concentration between 1 and $2 \mathrm{mg} / \mathrm{ml}$. Both the initial and secondary phase of insulin secretion appear to participate in the high responsiveness of fed pancreas to glucose stimulation. However, it is the shape and magnitude of the secondary phase which contributes most to the difference in total insulin secretion between fed and fasted pancreas.

Fasting did not affect the levels of glucose which trigger the typical type I and type II patterns of secondary response, but markedly depressed their overall magnitude. The resultant shift to the right of the dose-response curve, the elevation of the threshold for glucose and the decreased slope represent clear indications that fasting markedly reduces the sensitivity of the pancreas to one of its main physiologic stimuli. Recent studies with isolated islets suggest that the reduced sensitivity can be overcome with glucose concentrations in excess of $3 \mathrm{mg} / \mathrm{ml}$. (Wolters et al, unpublished observations).

Previous studies by Loubatières et al. on perfused pancreas $[23,24,25]$ and by Malaisse et al. on incubated pancreas $[4,26,28]$ have already established that sulfonylureas cause a marked shift to the left of the entire dose-response curve for glucose stimulation. It is noteworthy, that these studies were carried out with fed rat pancreas. Other perfusion studies so far reported, were conducted under fasting conditions and mainly concerned the effects of tolbutamide in the absence of glucose, or in the presence of a single high or multiple non-stimulating concentrations of glucose $[1,9,11,15,21]$.

In the present perfusion experiments with fed (and fasted) pancreas, the tolbutamide-induced additional output of insulin was highest at glucose $3 \mathrm{mg} / \mathrm{ml}$. This observation is at variance with the progressive reduction of the supplementary output of insulin at glucose levels in excess of $2 \mathrm{mg} / \mathrm{ml}$ as reported by Loubatières [24]. However, this author determined the supplementary output of insulin by administering tolbutamide after $45 \mathrm{~min}$ of stimulation with glucose alone. As stated by Loubatières [24] prestimulation with these high levels of glucose already induces a maximal response of the B-cells. In the present study, the effect of tolbutamide was measured by simultaneous application of both stimuli to the previously unstimulated preparation. Moreover, our $30 \mathrm{~min}$ period of continuous stimulation was hardly sufficient for reaching final (sub)-maximal secretion rates at any of the higher levels of glucose. 
Although tolbutamide may trigger some insulin release in the absence of glucose, the quantitative significance of this independent action seems negligible. Both in the fed and fasted state its predominant action consists of enhancing all characteristic aspects of glucose-induced insulin secretion. Thus, the potentiating effect on total insulin secretion as manifested by the shift to the left of the dose-response curve for glucose stimulation, is actually caused by a variety of different phenomena. These phenomena are particularly evident in the fed state.

At low glucose concentrations (below $1.5 \mathrm{mg} / \mathrm{ml}$ ) the shift is mainly due to a decrease of the glucose threshold effective in triggering type I patterns of secondary phase secretion and to the increased magnitude of the type I pattern. At glucose levels of $1.5 \mathrm{mg} /$ $\mathrm{ml}$ and higher the shift is caused by a decrease of the glucose threshold effective in triggering the type II pattern and to an increased magnitude of the type II response. The latter effect is due to acceleration of the glucose-induced progressive increase of the secretion rate. These findings lend further support to the idea that the action of tolbutamide involves some unidentified influence on the glucose dependent release mechanism at a level beyond the hypothetical glucoreceptors. It cannot be decided from our experiments whether or not tolbutamide can also increase the final maximal secretion rate attainable by prolonged maximal stimulation with glucose alone. The work of Loubatières [24] however suggests that this may not be the case.

In fasted rat pancreas the effects of tolbutamide were consistently less and even negligible at a glucose concentration of $2 \mathrm{mg} / \mathrm{ml}$. The percent inhibition of the tolbutamide-induced supplementary secretion at different glucose levels showed a pattern which was remarkably similar to the pattern of inhibition seen with glucose alone (Tables 4 and 5). This suggests that the inhibitory effect of fasting on the response to tolbutamide is also caused by primary inhibition of the glucose dependent release mechanism.

The mechanism by which fasting affects the release mechanism remains to be clarified. Various possibilities such as sensitivity of glucoreceptor sites, changes in islet metabolism and reduction of cyclic AMP should be considered. In fact, fasting has recently been shown to cause a selective depletion of the islet cyclic AMP content [31]. In accordance with previous observations $[12,30] 24-48 \mathrm{~h}$ of fasting did not exert any measurable effect on the total extractable insulin content. This implies that whenever biosynthesis or storage would be involved, one has to assume a reduction of a small hypothetical compartment from which insulin is being preferentially released on acute stimulation. The existence of such a compartment has been proposed [ 6 , $9,22]$.

Finally, the reduced sensitivity of fasted rat pancreas may not necessarily reflect true inhibition of islet function. This phenomenon could also imply a passive return to a low intrinsic basal level of sensitivity due to lack of stimulatory signals related to the intake of carbohydrate with meals. Suggestive evidence in support of this possibility has been obtained by Grey et al. [12]. Such a delayed acting "memory system" for islet sensitivity may constitute an important additional mechanism in the physiologic control of insulin secretion.

\section{References}

1. Basabe, J.C., Lopez, N.L., Viktora, J.K., Wolff, F. W.: Insulin secretion studied in the perfused rat pancreas. I. Effect of tolbutamide, leucine, and arginine; their interaction with diazoxide, and relation to glucose. Diabetes 20, $449-456$ (1971).

2. Bouman, P.R.: Release of insulin from isolated rat pancreas in vitro. Acta Endocr. (Kbh.) 35, 560-567 (1960).

3. Bouman, P.R., Gaarenstroom, J.H.: Stimulation by carbutamide and tolbutamide of insulin release from rat pancreas in vitro. Metabolism 10, 1095-1099 (1961).

4. Brisson, G.R., Malaisse, W.J.: Insulinotropic effect and possible mode of action of a new potent sulfonylurea (BS-4231). Can. J. Physiol. Pharmacol. 49, 536 544 (1971).

5. Buchanan, K.D., Vance, J.E., Williams, R.H.: Effect of starvation on insulin and glucagon release from isolated islets of Langerhans of the rat. Metabolism 18, 155-162 (1969).

6. Burr, I.M., Stauffacher, W., Balant, L., Renold, A. E., Grodsky, G.: Dynamic aspects of proinsulin release from perifused rat pancreas. Lancet 1969 II, 882 -883 .

7. Burr, I.M., Stauffacher, W., Balant, L., Renold, A. E., Grodsky, G.M. : Regulation of insulin release in perifused pancreatic tissue. Acta Diabet. Lat. 6, (suppl. 1), 580-596 (1969).

8. Coore, H.G., Randle, P.J.: Regulation of insulin secretion studied with pieces of rabbit pancreas incubated in vitro. Biochem. J. 93, 66-78 (1964).

9. Curry, D.L., Bennett, L.L., Grodsky, G.M.: Dynamics of insulin secretion by the perfused rat pancreas. Endocr. 83, 572-584 (1968).

10. Feldman, J.M., Lebovitz, H. E.: Effect of fasting on insulin secretion and action in mice. Endocr. 86, 313$321(1970)$.

11. Fußgänger, R.D., Goberna, R., Hinz, M., Jaros, P., Karsten, C., Pfeiffer, E.F., Raptis, S.: Comparative studies on the dynamies of insulin secretion following HB 4.19 and tolbutamide of the perfused isolated rat pancreas and the perifused isolated pieces and islets of rat pancreas. Horm. Metab. Res. Suppl. ad Vol. 1, $34-40(1969)$.

12. Grey, N.J., Goldring, S., Kipnis, D.M.: The effect of fasting, diet, and actinomycin $\mathrm{D}$ on insulin secretion. in the rat. J. clin. Invest. 49, 881-889 (1970).

13. Grodsky, G.M., Batts, A.A., Bennett, L.L., Veella, C., MoWilliams, N.B., Smith, D.F.: Effects of carbohydrates on secretion of insulin from isolated rat pancreas. Amer. J. Physiol. 205, 638-644 (1963).

14. Grodsky, G.M., Bennett, L.L.: Cation requirements for insulin secretion in the isolated perfused pancreas. Diabetes 15, $910-912(1966)$.

15. Grodsky, G.M., Bennett, L. L., Smith, D.F., Nemechek, K.: The effect of tolbutamide and glucose on the timed release of insulin from the isolated perfused rat pancreas. In: Butterfield, W.J.H., van Westering, W., eds.: Tolbutamide after ten years, p. 11-21. Amsterdam: Excerpta med. Foundation 1967. 
16. Grodsky, G.M., Lee, J., Licko, Y., Landahl, H.: Characteristics of multiphasic insulin release in vitro. In: Rodriguez, R.R., Vallance-Owen, J., eds.: Diabetes, Proceedings of the seventh congress of the international diabetes federation, Buenos Aires, 1970 , p. 427-442. Amsterdam: Excerpta med. 1971.

17. Junod, A., Letarte, J., Lambert, A.E., Stauffacher, W.: Studies in spiny mice (Acomys Cahirinus) : metabolic state and pancreatic insulin release in vitro. Horm. Metab. Res. 1, 45-52 (1969).

18. Konijnendijk, W., Bouman, P.R. : Insulin-like activity and immunoreactive insulin content of gelfiltered protein fractions of bovine serum. Diabetologia 6, 379-385 (1970).

19. Lacy, P.E., Kostianovsky, M.: Method for the isolation of intact islets of Langerhans from the rat pancreas. Diabetes 16, 35-39 (1967).

20. Landgraf, R., Kotler-Brajtburg, I., Matsehinsky, F. M. : Kinetics of insulin release from the perfused rat pancreas caused by glucose, glucosamine and galactose. Proc. nat. Acad. Sci. USA 68, 536-540 (1971).

21. Laube, H., Fußgänger, R., Goberna, R., Schröder, K., Straub, K., Sussman, K., Pfeiffer, E. F. : Effects of tolbutamide on insulin and glucagon secretion of the isolated perfused rat pancreas. Horm. Metab. Res. 3, $238-242(1971)$

22. Lee, J.C., Grodsky, G.M., Bennett, L.L., SmithKyle, D.F., Craw, L.: Ultrastructure of $\beta$-cells during the dynamic response to glucose and tolbutamide in vitro. Diabetologia 6, 542-549 (1970).

23. Loubatières, A.: Physiological and pharmacological aspects of the central role of the pancreas in the mode of action of hypoglycemic sulfonamides. Acta Diabet. Lat. 6 (suppl. 1), 216-255 (1969).

24. Loubatières, A.: Pharmacological aspects of insulin secretion. In: Rodriguez, R.R., Vallance-Owen, J., eds.: Diabetes, Proceedings of the seventh congress of the international diabetes federation, Buenos Aires, 1970 , p. $137-158$. Amsterdam: Excerpta med. 1971.

25. Loubatières, A., Mariani, M.M., Chapal, J. Insulinosécrétion etudiée sur le pancréas isolé et perfusé du rat. I. Synergie entre glucose et sulfamides hypoglycémiants. Diabetologia 6, 457-466 (1970).

26. Malaisse, W.J., Malaisse-Lagae, F.: Effects of glycodiazin and glibenclamide upon insulin secretion in vitro. Europ. J. Pharmacol. 9, 93-98 (1970).

27. Malaisse, W.J., Malaisse-Lagae, F., Lacy, P.E., Wright, P.H.: Insulin secretion by isolated islets in presence of glucose, insulin and anti-insulin serum. Proc. Soc. exp. Biol. Med. 124, 497-500 (1967).

28. Malaisse, W.J., Malaisse-Lagae, F., Mayhew, D.A., Wright, P.H.: Effects of sulfonylureas upon insulin secretion by the rat's pancreas. In: Butterfield, W.J. H., van Westering, $W$., eds.: Tolbutamide after ten years, p. 49-60. Amsterdam: Excerpta med. Founda. tion 1967.

29. Malaisse, W., Malaisse-Lagae, F., Wright, P.H.: A new method for the measurement in vitro of pancreatic insulin secretion. Endocr. 80, 99-108 (1967).

30. Malaisse, W.J., Malaisse-Lagae, F., Wright, P.H.: Effect of fasting upon insulin secretion in the rat. Amer. J. Physiol. 213, 843-848 (1967).

31. Selawry, H., Voyles, N., Gutman, R., Wade, A., Fink, G., Recant, L.: Elffect of starvation on tissue and islet cAMP levels. Diabetes 21, 329 (1972).

32. Sussman, K.E., Vaughan, G.D., Timmer, R.F.: An in vitro method for studying insulin secretion in the perfused isolated rat pancreas. Metabolism 15, 466$476(1966)$.

33. Umbreit, W.W., Burris, R.H., Stauffer, J.F. : Manometric techniques, 3 rd ed., p. 149. Minneapolis: Burgess Publishing Co. 1957.

34. Yalow, R. S., Berson, S.A.: Immunoassay of endogenous plasma insulin in man. J. clin. Invest. 39, $1157-1175(1960)$.

R.S. Bosboom, M.D.

Endocrine Research Unit

Department of Pharmacology

1 Bloemsingel

Groningen

The Netherlands 